\title{
Why fight secession? Evidence of economic motivations from the American Civil War
}

\author{
Zachary Liscow
}

Received: 12 July 2010 / Accepted: 8 February 2011 / Published online: 23 February 2011

(C) The Author(s) 2011. This article is published with open access at Springerlink.com

\begin{abstract}
Why fight secession? This paper is a case study on this question, asking why the North chose to fight the South in the American Civil War. It tests a theoretical prediction that economic motivations were important, using county-level presidential election data. If economic interests like manufacturing wished to keep the Union together, they should have generated votes to do so. That prediction is borne out by the data, and explanations other than Northern economic concerns about Southern secession appear unable to explain the results, suggesting that economic motivations were important to support for fighting the South.
\end{abstract}

Keywords Voting · War - Secession · American Civil War

JEL Classification $\mathrm{D} 72 \cdot \mathrm{H} 77 \cdot \mathrm{N} 41$

\section{Introduction}

Even after Abraham Lincoln was elected president of the United States in 1860, powerful Northern interests opposed war with a seceded South. For example, three days after Lincoln's election, the influential New York Tribune wrote, "If the cotton states shall decide that they can do better out of the Union than in it, we insist on letting them go in peace."1 The public did not consider war inevitable, even after the secession of most of the Confederacy before the Fort Sumter attack (Stampp 1970). The South was poorer than the North. Were the South to secede, it would not pose an immediate threat to the North. Yet, in Lincoln's immortal words from his Second Inaugural Address, "the war came." By testing an economic explanation, I seek to help answer the question of why-given that the South had seceded - the North chose to fight.

\footnotetext{
${ }^{1}$ New York Tribune, November 9, 1860, from Bailey et al. (1998).

Z. Liscow $(\bowtie)$

Department of Economics, University of California, Berkeley, 508-1 Evans Hall \#3880, Berkeley, CA 94720, USA

e-mail: liscow@econ.berkeley.edu
} 
This paper is a case study addressing a more general question: why fight secessions? A variety of explanations have been offered. Bolton and Roland (1997) suggest that the efficiency gains from having one unified market may justify fighting secessions. Walter (2006) finds that nations may seek to build a reputation for opposing secession so that other regions do not secede. Others have suggested that the seceding regions may be important for defense, for psychological and historical reasons, or for providing economic value to the rest of the country (e.g., Bartkus 1999; Coakley 1993; Huth 1996; Touval 1972). This paper tests the proposition that economic considerations may have been important in the American Civil War.

Many important studies of the Civil War barely discuss why the North decided to fight the South after it seceded, instead focusing almost entirely on the decision-making of the South (e.g., Potter 1942; McPherson 1988). History textbooks often note that the North seemed to oppose war; then the South attacked the Union at Fort Sumter in April 1861. After that, Northern support for war built rapidly. To simplify, one standard textbook says that Lincoln-for complex and unclear reasons - decided to hold onto Fort Sumter and send it foodstuffs; after the South attacked it, war was a foregone conclusion (Bailey et al. 1998). The federal government was merely enforcing the laws, Lincoln and the Republicans said (McPherson 1988).

The economics literature has discussed the question of the North's motivation. Gunderson (1974) argues that the North may have wanted to prevent the spread of slavery. Ransom (2001) notes several economic tensions between the North and the South, but says that most historians think that the North's decision was non-economic. Wright (1978) argues that a desire to maintain the Union among the Northern leadership was decisive.

Another explanation, described in the work of DiLorenzo (2003, 2006) and Stampp (1970), is that manufacturing interests in the North benefited from keeping the South in the Union. DiLorenzo (2003) provides narrative evidence for his argument. This study is the first attempt to formally test an economic explanation of why the North chose to fight the South and quantify its importance. ${ }^{2}$ To do this, the study uses controlled regressions with large and relatively disaggregated datasets on the county level.

Specifically, using voting patterns as representations of the Northern population's preferences, this paper tests empirically whether the economic motivations of its manufacturing interests might have been important components of Northerners' support of the decision to fight. The hypothesis that the North had economic motivations for keeping the South in the Union yields a specific prediction: counties with relatively large amounts of these manufacturing interests should shift their votes from Democrats to Republicans between 1860 and 1864. The reason is the following: the best way to keep the South in the Union before the Civil War was to vote for the Democrats, reducing the likelihood of secession by voting for the party more accommodating to Southern slavery interests. However, the best way to keep the South in the Union during the war was to vote for the Republicans, who were more likely to pursue the war until victory was achieved.

Using county-level census data and voting data from the 1860 and 1864 presidential elections, I find that there is a significant shift toward the Republicans associated with manufacturing employment. This shift toward the Republicans associated with manufacturing together amounts to $2.25 \%$ of voters in Northern states; that is, taking the results literally suggests that $2.25 \%$ of Northern voters shifted their votes to the Republicans out of a desire to protect their manufacturing interests by keeping the South in the Union.

\footnotetext{
${ }^{2}$ Egnal (2001) uses a somewhat similar methodology with county-level voting data to discern shifting interests before the Civil War.
} 
The remainder of the paper proceeds as follows. I first review the possible economic causes of the North's decision. Then I explain the empirical methodology, followed by the paper's data. After presenting the paper's main results, I present robustness checks and argue that other explanations are unlikely to account for the reported shifts in voting patterns. Finally, after interpreting the results, I conclude.

\section{Theory and anecdotal evidence: explanations of the North's decision to fight}

The debate on whether economic considerations were important causes of the Civil War is decades old. In the 1920s, Beard and Beard (1927) made a classic argument for the importance of economic motivations, saying that structural economic differences were the Civil War's primary cause. The North wanted a strong national government which could promote economic development; the South preferred strong states and did not want to spend the money for that expansionism. Indeed, the idea that a main effect of the Civil War was the triumph of industrial capitalism in the United States has come to be known as the "BeardHacker" thesis. While the Beards' work does not go far in explaining why the North did not allow the South to secede, these arguments helped spawn a literature that focused on the economic differences between the North and the South.

This paper tests whether manufacturing interests may have been important to the North's decision to fight the South. Stampp (1970) provides anecdotal evidence that manufacturing interests anticipated being harmed by secession of the South. For example, although there could be multiple explanations for this, he notes that "between January 1860 and January 1861 , the average price of a share of stock in forty-four cotton and woolen mills declined from \$518.34 to \$304.22.”3 Likewise, John Parsons Foote, the abolitionist uncle of Harriet Beecher Stowe and an astute observer of the economic atmosphere before the war, wrote the following to his industrialist brother Samuel Edmond Foote: "You Connecticut folks support the slave powers because you can send your clocks and buttons among the slave drivers" (Foote 1854).

More specifically, there are three economic reasons why Northern manufacturers might have wanted to keep the South as part of the Union. First, they may have wanted to maintain the Southern market for tariff-protected manufactured goods priced above the foreign competition. If the South had seceded, Northern manufacturers would presumably have faced the same import tariff in the South that Europeans faced, putting the two on equal footing. Domestic manufacturers-mostly Northern-had substantial advantages over the foreign competition in access to domestic markets: in 1860, a low-point of $19^{\text {th }}$ century tariff rates, import taxes amounted to $15.67 \%$ of the value of all imports and $19.67 \%$ of the value of dutiable imports; in 1864, the taxes amounted to $32.04 \%$ of all imports and $36.69 \%$ of dutiable imports. ${ }^{4}$ By comparison, import taxes amounted to $7.40 \%$ of all imports and $12.22 \%$ of dutiable imports in 1960.

Second, Northern manufacturers feared a long, porous southern border, through which goods unprotected by tariffs could flow northward, undercutting the prices of their more expensive goods (Foner 1941; Stampp 1970). For example, the London Times said in March 1861, after some Southern states seceded, that European businessmen had perceived this

\footnotetext{
${ }^{3}$ Stampp (1970: 124). Note that this was not a time of deflation.

${ }^{4}$ U.S. Census Bureau (1970). These numbers understate the true impact of the tariff, since highly-protected goods will represent a smaller portion of total imports than they otherwise would, while still protecting domestic producers.
} 
opportunity to invade the Northern market claiming, "The smuggler will redress the errors of the statesman." ${ }^{5}$ The New York Evening Post described the horrifying prospect of all imports coming through the South and "the whole country ... given up to an immense system of smuggling." Some at the time even suggested that the agrarian West might choose to join the free-trade South to avoid large tariffs, further harming both industrial and trading prospects. ${ }^{7}$ Indeed, Cincinnati began receiving goods tariff-free from New Orleans in 1861 (Stampp 1970). The high rate of tariffs makes such claims more plausible.

Third, manufacturers may have wanted continued reliable access to Southern primary goods, particularly "King Cotton." The South punitively could have refused to sell its agricultural products to the North-or threatened to do so, in order to gain clout in "international" negotiations. Though the Transportation Revolution was in full swing, bulky commodities were still somewhat costly to ship from far away, so primary goods from outside the South would have carried higher prices owing to greater transportation costs. ${ }^{8}$ Also, given the state of mid- $19^{\text {th }}$ century communication technology, obtaining primary products from outside the South would have increased transaction costs other than those for transportation. Even if the South did not ever threaten to disrupt a steady supply of agricultural products, the need to trade between two countries could have increased manufacturers' transaction costs. Presumably partly for these reasons, McPherson (1988) notes that the price of a pound of cotton in the North increased from ten cents to a dollar during the war.

Northern editorials raised these concerns about manufacturing. For example, on December 10, 1860, the Daily Chicago Times noted that the tariff

"protects our manufacturers ... and enables [the North] to consume large quantities of Southern cotton. This operates to compel the South to pay an indirect bounty to our skilled labor, of millions annually. ... Let the South adopt the free-trade system ... [and the North's] commerce must be reduced to less than half what it now is.... Our labor could not compete ... with the labor of Europe."9

The passage raises all three of the above concerns: the access to Southern primary goods like cotton, the "indirect bounty" from selling tariff-protected goods to the South, and the need to compete with European labor should a free trade South secede, presumably partly due to a porous border. Similarly, on April 2, 1861, the Newark Daily Advertiser warned that Southerners had apparently "taken to their bosoms the liberal and popular doctrine of free trade" and that they "might be willing to go ... toward free trade with the European powers," which "must operate to the serious disadvantage of the North." ${ }^{10}$ This editorial emphasizes that the presence of a free trade South was a credible threat that would damage the North.

Similarly, some critics in the North emphasized the economic interests at stake in the war. As emphasized by DiLorenzo (2006), abolitionist and legal scholar Lysander Spooner argued in 1870 that the war "erupted for a purely pecuniary consideration," largely the value of having "control of [Southern] markets" to be able to enforce tariff "extortion." The war

\footnotetext{
${ }^{5}$ London Times, quoted in New York Herald, March 17, 1961, from Stampp (1970).

${ }^{6}$ New York Evening Post, March 12, 1961, from Stampp (1970).

${ }^{7}$ Westerners were a minority, so they might have been unable to block the imposition of tariffs.

${ }^{8}$ There may have been smuggling from the South, but cotton is so bulky that this is unlikely to have helped Northern manufacturers very much.

${ }^{9}$ Daily Chicago Times, December 10, 1860, from DiLorenzo (2003).

${ }^{10}$ Newark Daily Advertiser April 2, 1861, from DiLorenzo (2003).
} 
would allow "such tariffs on imports as will enable our home manufacturers to realize enormous prices for their commodities" (Smith 1992: 117-118). ${ }^{11}$

\section{Empirical method}

I evaluate the hypothesis that maintaining manufacturing employment was an important motivation of the North's decision to fight the South by testing a prediction of the hypothesis using presidential election voting data. The prediction is based on the assumption widelyaccepted in public choice that people vote their economic interests, suggesting that voters with an economic interest in keeping the South in the Union should vote as such (Persson and Tabellini 2000). Particularly, counties with a relatively large manufacturing sector should shift their votes from Democrats to Republicans between 1860 and 1864 relative to those with a smaller manufacturing sector. The reasoning is the following: the best way to keep the South in the Union before the Civil war was to vote for the Democrats, reducing the likelihood of secession by voting for the party more accommodating to Southern slavery interests. However, the best way to keep the South in the Union during the war was to vote for the Republicans, who were more likely to pursue the war until victory. ${ }^{12}$

In the 1860 presidential election, before the Civil War, the best way to keep the South in the Union was to vote for the Democrats. Southerners were clear that a victory by the Republican candidate Abraham Lincoln over Democrats Stephen Douglas and John Breckinridge and Constitutional Union candidate John Bell meant disunion. ${ }^{13}$ McPherson writes that even border state Unionists, like John Crittenden, "Kentucky's elder statesman of unionism," warned Northerners that a Lincoln victory would lead to disunion (McPherson 1988: 229-230). Warnings were often very explicit. For example, Georgia's leading Douglassupporting newspaper wrote, "Let the consequences be what they may-whether the Potomac is crimsoned in human gore, and Pennsylvania Avenue is paved ten fathoms deep with mangled bodies ... the South will never submit to such humiliation and degradation as the inauguration of Abraham Lincoln" (McPherson 1988: 230). Southerners meant what they threatened: within three months of Lincoln's election, the Confederate States of America had drafted a constitution and established a capital at Montgomery, Alabama.

\footnotetext{
${ }^{11}$ Historians have also offered a variety of non-economic explanations for the North's decision to fight the South. Since they are not tested in this paper, I will mention the explanations only briefly here. In addition to the claim that the attack on Fort Sumter spurred the North to fight, explanations include: a nationalistic commitment to preserving the Union (Nagel 1964; Ransom 1989), the leadership's commitment to the Union (Wright 1978), a moral commitment to containing or eliminating slavery (Gunderson 1974), sectional animosity (Owsley 1941; Ransom 1989), and the Republicans' desire not to lose the Union under their watch (Stampp 1970). Also see Fogel (1989) and North (1961). Other economic interest groups include those concerned about disruption of Mississippi River shipping and those involved in international trade, who would lose from trade being rerouted to a free-trade South or a Southern blockade of trade from the rest of the Americas (Foner 1941; Hummel 1996; Stampp 1970).

${ }^{12}$ Note that universal white male suffrage for U.S. citizens 21 and older was essentially achieved before 1860 (Porter 1918; Rusk 2001; Williamson 1960). There were small variations across states in this sample in 1860 and 1864, with a few requiring payment of a state or county tax, some allowing blacks to vote, some requiring up to two years of state residency and others requiring none, and some allowing non-citizens to vote. However, the analysis of Rusk (2001) shows that approximately 50\% of adults outside the South were eligible to vote in the 1850s and 1860s, suggesting nearly complete adult male suffrage. Additionally, there were not significant changes between 1860 and 1864, suggesting that this factor is not an important confound (Rusk 2001, Chap. 2 tables).

${ }^{13}$ Those interested in maintaining the Union could also vote for the Constitutional Union Party, which only $2.4 \%$ of voters did.
} 
In contrast, the best way to keep the South in the Union in 1864, during the Civil War, was to vote for the Republicans. In the 1864 election between Union/Republican ${ }^{14}$ candidate Abraham Lincoln and Democratic candidate George McClellan, the parties differed substantially on their opinion of the war, since the platform of the Democrats officially declared the war a failure and the Union Party strongly supported continued fighting. ${ }^{15}$ Although Democratic candidate McClellan largely ignored the platform and ran on a platform of supporting the war, it was clear that the South interpreted the Lincoln victory as a strike for the Union. For example, Southern soldiers shouted, "Hurrah for McClellan!" (Bailey et al. 1998). Additionally, after Lincoln's victory, desertions from the Southern army sharply rose, suggesting that they viewed Lincoln's victory as a sign of the Union's commitment to the war (Bailey et al. 1998: 479).

Thus, economic interests yield a clear prediction: in counties with a large manufacturing sector, ceteris paribus, there should be an increase in the Republican vote share between 1860 and 1864 . Using county-level data, I test this hypothesis by running a controlled regression of the difference between the 1864 and 1860 Republican vote shares on the manufacturing employment share and covariates, using state dummies.

To understand the econometric specification used in this paper, first consider the two levels specifications:

$$
\begin{aligned}
& y_{1 i}=\alpha_{1}+x_{i} \beta_{1}+c_{i} \gamma_{1}+d_{i} \delta+\phi_{1 s}+\varepsilon_{1 i}, \\
& y_{2 i}=\alpha_{2}+x_{i} \beta_{2}+c_{i} \gamma_{2}+d_{i} \delta+\phi_{2 s}+\varepsilon_{2 i},
\end{aligned}
$$

where (1) and (2) represent the equations for 1860 and 1864, respectively. In these equations, $i$ indexes counties, $s$ indexes states, $y_{t i}$ is the Republican vote share in year $t, x_{i}$ is a vector of variables with time-invariant values but potentially time-varying effects $\left(\beta_{t}\right)$ on voting, $c_{i}$ is a vector of control variables which also have time-invariant values but potentially time-varying effects $\left(\gamma_{t}\right)$ and which are potentially correlated with both $x_{i}$ and $y_{t i}, d_{i}$ is a vector of unobserved variables which have time-invariant values and effects and which are potentially correlated with both $x_{i}$ and $y_{t i}, \phi_{t s}$ is a vector of state dummies with potentially time-varying values, and $\varepsilon_{t i}$ is a time-varying error term. In the preferred specification below, $x_{i}$ consists of per capita manufacturing employment. Another specification adds to $x_{i}$ per capita employment by manufacturers which process Southern agricultural commodities, like cotton and tobacco. Note that, since $d_{i}$ is unobserved, it is not possible to calculate its coefficients in (1) and (2), and running the regressions without $d_{i}$ would yield inconsistent estimators.

Instead, taking the difference between (1) and (2) yields:

$$
\Delta y_{i}=\Delta \alpha+x_{i} \Delta \beta+c_{i} \Delta \gamma+\Delta \phi_{s}+\Delta \varepsilon_{i}
$$

where $\Delta$ represents the change between 1860 and 1864. Since neither $d_{i}$ nor its effect, $\delta$, is time-varying, both fall out of the equation. Note that, throughout the paper, coefficient estimates refer to the change in the effect of the given variable on the Republican vote share.

\footnotetext{
${ }^{14}$ The Republicans joined with pro-war Democrats to temporarily form the Union party.

${ }^{15}$ The war was going poorly for the Union until shortly before the election, when the North scored several victories, like Admiral Farragut's capture of Mobile, Alabama, and General Sherman's seizure of Atlanta, Georgia (Bailey et al. 1998).
} 
The presence of economic motivations predicts a positive coefficient on each element of the $\Delta \beta$ vector. $^{16}$

The identifying assumption of (3), which follows from the validity of (1) and (2), is that $x_{i}$ is uncorrelated with $\Delta \varepsilon_{i}$; that is, the main explanatory variables are uncorrelated with the error term. Conditional on changes in state dummies and changing effects of the control vector, the main explanatory variables must be uncorrelated with other causes of the change in Republican vote share. The key is that these equations measure a shift in votes so that any unobservable which does not change its effect on the likelihood of voting for the Republicans between 1860 and 1864 is differenced out and does not threaten the consistency of the estimators.

Also, since I add state dummies to control for any characteristic common to states which might shift its influence between 1860 and 1864, results are identified off of intra-state differences. This is valuable since the states from which candidates come influence electoral outcomes, and the importance of manufacturing varies by state.

In my main specifications, I use two controls. First, I control for the number of foreignborn people. Immigrant voters may live disproportionately in areas with more manufacturing. Also, given the Republican Party's strong anti-immigrant sentiment (Silbey 1985), it is possible that the foreign-born, even those working in manufacturing, would be less susceptible to shifting to the Republican Party than the native-born. Thus, a greater fraction of foreign-born voters might lead to a smaller shift in Republican votes, correlated with a larger amount of manufacturing.

Second, I control for the logarithm of population density, since factors associated with cities (like cultural attitudes) are correlated with manufacturing activity and thus could be an important omitted variable. These cultural attitudes could potentially change their effect over time as ideas changed disproportionately fast in urban areas.

I weight the regression by population size, since what really matters to the question here is the total population, not an average of county-level attitudes among counties which have very different populations. Thus, weighting by population gives a more accurate sense of the opinion in the North at the time. ${ }^{17}$

Note that this methodology assumes that popular opinion mattered for the decision to fight the South. For example, if Lincoln made the decision to fight the South without any regard for Northern opinion, then that opinion would be meaningless. For example, Wright (1978: 156) argues that the decisions regarding whether to fight the South "must be studied at the level of small-group behavior, albeit behavior influenced by perceptions of a social background." However, others argue that Lincoln was quite "sensitive to the drift of public opinion" (Stampp 1970: 189). Thus, there is agreement that public opinion played a role in the decision to go to war; the question is how much. That will not be answered here, but the question of what drove public opinion remains a useful one.

The interpretation of the results using this methodology depends upon whether one assumes that the workers employed in manufacturing enterprises had interests aligned with the owners, insofar as Southern secession was concerned. This assumption is reasonable,

\footnotetext{
${ }^{16}$ Following the guidance of Stock and Watson (2003), all regressions use heteroskedastic-robust standard errors, since there are not compelling reasons to believe that errors would be homoskedastic.

${ }^{17} \mathrm{~A}$ second reason is that, since the observations represent averages within counties, smaller counties will have larger "sampling" variances. Weighting by population yields a more efficient estimator, since observations from counties with larger populations are more precisely estimated. Note that weighting by number of voters may be more ideal; however, this variable is not available.
} 
since harm to manufacturing would lower wages for laborers. ${ }^{18}$ Indeed, it was a longstanding Whig and Republican belief that the interests of owners and workers were aligned, as demonstrated particularly by the notion "that the protective tariff was designed primarily to advance the interests of labor" (Foner 1970: 20). ${ }^{19}$ Even without this assumption, the per capita sectoral employment variables could be seen as proxies for the manufacturing interests in an area. However, given the reasonableness of the assumption, I will interpret the results as representing the changing preferences of those who worked in these industries.

\section{Data}

The data for this study come from several sources. First, the explanatory variables on male manufacturing employment, total population, and foreign population come from the 1860 U.S. Census of Population and Housing, from the Geospatial and Statistical Data Center at the University of Virginia Library (2004). Additional control variables on church seats per capita, per capita cash value of farms, and per capita capital invested in manufacturing also come from this source. Disaggregated data on manufacturing employment, used as a measure of manufacturing using Southern agricultural goods, were not available electronically, so I coded this manually from the 1860 Census of Manufactures. For the explanatory variable, per capita employment in manufacturing with Southern agricultural goods, I add together employment in firms processing cotton, sugar, and tobacco, as well as producing paint and chemicals. ${ }^{20}$

The dependant variable, the difference between the percent of the presidential vote received by the Republican candidate at the county level in 1860 and 1864 from counties in Union states, is from the Interuniversity Consortium for Political and Social Research (Clubb et al. 2006). Votes from soldiers are not included, since they are tabulated at the state level. The number of soldier votes missing from the analysis is difficult to determine, since only the fraction voting for each party — not the number of votes - is provided in the data. However, with approximately 2,100,000 men participating in the Union army over the course of the war and a Union population of approximately 20,000,000, if half of the total was serving in 1864 and all of them voted, then approximately $10 \%$ of voters would be removed from the analysis (McPherson 1988). ${ }^{21}$

The dataset for the baseline regressions is limited to 716 counties for several reasons. First, only non-border state members of the Union during the Civil War are included. Border states (Missouri, Delaware, Kentucky, and Maryland) cannot be included, since many counties had no votes recorded for the Republican candidate in 1860, presumably since there were no local Republican organizations to distribute ballots, making shifts in voting impossible to discern. A further factor is that many counties in Missouri had extremely high vote shares-some as high as $100 \%$ - for the Republican in 1864, perhaps a result of the Union

\footnotetext{
${ }^{18}$ This assumes the absence of costless migration of labor and capital to the South, where workers could again be employed in the un-tariff-protected trade there. Without costless migration of capital, it may have taken some time for industry to develop in the South.

${ }^{19}$ Similarly, manufacturing unions today often support tariffs.

${ }^{20}$ Paint and chemicals are included due to Southern production of turpentine. Employment in these sectors is small and affects the results little.

${ }^{21}$ County areas from the 1950 City and County Data Book, also accessed from the Interuniversity Consortium for Political and Social Research, were used to compute population densities, along with historical research to determine the size of the half-dozen counties which changed sizes or no longer existed in 1950.
} 
Table 1 Summary statistics, weighted by population size

\begin{tabular}{lcccc}
\hline Variable & Mean & $\begin{array}{l}\text { Standard } \\
\text { Deviation }\end{array}$ & Minimum & Maximum \\
\hline $\begin{array}{l}\text { Change in fraction Republican vote share between 1860 } \\
\text { and 1864 }\end{array}$ & 0.0006 & 0.0751 & -0.3800 & 0.7390 \\
$\begin{array}{l}\text { Employment in manufacturing } \\
\begin{array}{l}\text { Employment in manufacturing with Southern agricultural } \\
\text { goods }\end{array}\end{array}$ & 0.0568 & 0.0615 & 0.0005 & 0.4841 \\
$\begin{array}{l}\text { Fraction of population of foreign origin } \\
\text { Log population density (persons / sq. mi.) }\end{array}$ & 0.0070 & 0.0000 & 0.0750 \\
\hline
\end{tabular}

Note: There are 716 observations, except for employment in manufacturing with Southern agricultural goods, which has 674. The sample includes all counties from non-border Union states with data for manufacturing employment and the control variables. The employment variables are measured as a fraction of total county population

Source: Clubb et al. (2006), Geospatial and Statistical Data Center (2004), and 1860 Census of Manufactures

military presence or boycotts by non-Republican voters. Heterogeneous voter boycotts, military presence, and absence of the Republican Party in 1860 would add a great deal of noise to the results, at best, so these states were excluded.

Second, in the main specifications, I drop counties which had border changes between 1860 and 1870 to limit measurement error arising from those changes. ${ }^{22}$ This results in 33 dropped counties. Including the variable on manufacturing with Southern agricultural goods results in additional dropped counties, leaving 674.

Summary statistics, weighted by population size, are tabulated in Table 1 . The table shows that, among the states studied, Republicans gained virtually no overall vote share between 1860 and 1864. However, there is a substantial amount of variation, with a standard deviation of 7.51 percentage points. Manufacturing employed $5.68 \%$ of the population.

I use presidential election results, rather than votes on important pre-war bills in Congress, for several reasons. First, studying presidential elections allows the use of data closer to the time of Southern secession and the Northern declaration of war. Many of the important votes in Congress were in the early 1850s, whereas the relevant presidential elections happened right before and after these events. Second, since there are more counties than congressional districts, using counties yields a greater number of observations. Third, all of the data used here are at the county level; constructing congressional districtlevel data would require combining data from counties within multi-county congressional districts, adding measurement error. Similarly, two rather different congressional districts within the same county would be assigned the same data. Likewise, congressional districts change over time, further complicating measurement. Finally, Members of Congress may vote strategically - for example voting in favor of pro-slavery policies in return for votes for pro-development economic policy (Weingast 1998). It is likely that, due to uncertainties over electoral outcomes and coordination problems, voters are less likely to be able to vote strategically, making their votes a more accurate representation of their preferences. ${ }^{23}$

\footnotetext{
${ }^{22}$ I use Thorndale and Dollarhide (1987) to determine which counties had border changes between 1860 and 1870 .

${ }^{23}$ I also do not analyze votes for congressional candidates because candidate-specific characteristics would add noise to the results.
} 
Table 2 Change in fraction Republican vote share between 1860 and 1864

(1)

Employment in manufacturing

\subsection{7}

Employment in manufacturing without

Southern agricultural goods

Employment in manufacturing with Southern

agricultural goods

Fraction of population of foreign origin

Log population density (persons/sq. mi.)

Constant

Observations

$R^{2}$

* Significant at the $10 \%$ level

** Significant at the $5 \%$ level

**** Significant at the $1 \%$ level

Note: Robust standard errors are in brackets. The regressions are population-weighted. The employment variables are measured as a fraction of total county population

Source: Clubb et al. (2006), Geospatial and Statistical Data Center (2004), and 1860 Census of Manufactures
(2)

$0.330^{* * *}$

[0.123]

[0.0876]

(3)

(4)

$0.396^{* * *}$

[0.118]

$0.382^{* * *}$

[0.126]

0.608

[0.436]

$-0.192^{* * *}-0.192^{* * *}$

[0.0379] [0.0380]

$0.0117^{* * *} \quad 0.0117^{* * *}$

$-0.146^{* * *}-0.146^{\text {*** }}$

$[0.00409] \quad[0.0241] \quad[0.0251] \quad[0.0250]$

$\begin{array}{llll} & \times & \times & \times \\ 716 & 716 & 716 & 674\end{array}$

$\begin{array}{llll}0.011 & 0.474 & 0.516 & 0.513\end{array}$

[0.00388] [0.00390]

\section{Main results}

Table 2 presents the main results of the paper. The bivariate regression in column (1) is "right"-signed but not significant. Adding state dummies in column (2) nearly triples the coefficient, emphasizing the importance of state as an omitted variable. Column (3), the paper's preferred specification, further adds controls on the foreign-born population and log population density, finding that the fraction of the population in manufacturing is strongly related to a shift the Republican vote share and is significant at the $0.1 \%$ level.

Column (4) disaggregates manufacturing employment into that using Southern agricultural goods and that which does not. The coefficient on manufacturing with Southern agricultural goods is significantly larger than that on manufacturing with non-Southern manufacturing goods, though it is not significant. Given the large standard error, this analysis does not provide evidence either in favor of or against the hypothesis that access to Southern primary products was an important part of the North's motivation for keeping the South in the Union.

For interpretation, I focus on column (3). Conducting the thought experiment of what happens to the shift in the Republican vote share as the population share of each employment group goes from zero to its population-weighted average value provides one interpretation of the results. One can calculate this by multiplying each coefficient by the weighted average of its associated regressor and adding these results together. A one percentage point increase in the fraction of the population in manufacturing increases the voting share for Republicans by 0.396 percentage points, and the average employment rate in manufacturing is $5.68 \%$. 
Multiplying the two together yields a shift in the Republican vote share of 2.25 percentage points associated with manufacturing employment.

Given that ten percentage points separated the two candidates in the 1864 election and a swing of a little over five percentage points would have changed the popular vote outcome, 2.25 percentage points is substantial. To better understand the meaning of the coefficient on manufacturing, given Electoral College concerns and the unequal distribution of manufacturing, I look at states whose voting outcome would have changed without this effect of manufacturing employment. With Lincoln's victory of only 0.92 percentage points in New York and 3.51 percentage points in Pennsylvania, the country's two largest states at the time, as well as a difference of 2.76 percentage points in Connecticut, these three states would have shifted their votes to the Democrats in the 1864 election without this effect of manufacturing. ${ }^{24}$ While not enough to swing the election, this outcome would have shifted over a quarter of the electoral votes to the Democrats (65 out of a total of 233), yielding a 147-86 result in the Electoral College.

\section{Robustness checks}

Several robustness checks confirm the general results shown above. A first set of robustness checks, shown in Table 3, adds various controls to the preferred specification, column (3) in Table 2. In all cases, the results are little-changed. One concern might be a reversion to the mean in vote share between 1860 and 1864, so column (1) adds the Republican vote share in 1860. Another concern might be that manufacturers switch their votes to the Republicans because they are making armaments for a war which lasted surprisingly long. Column (2) adds a control for those employed in weapons manufacturing; this does not change the results, although the coefficient on weapons manufacturing itself is not precisely estimated. Controlling for church accommodation per capita (which might matter because of the religious connection to abolitionism) in column (3) and the cash value of farms per capita (which would matter if there were trends in farm areas) in column (4), as well as including all five of these controls together in column (5), does not substantively change the results.

Table 4 shows several robustness checks involving changed specifications. Column (1) runs the preferred specification without weights, and column (2) includes the 33 counties removed due to changing county boundaries. In both cases, the coefficient stays highly significant, though it is somewhat smaller. Since counties with changing boundaries may add noise, attenuating the results, this is expected.

Column (3) adds per capita capital invested in manufacturing as a kind of falsification test. If what is really driving the association between manufacturing and shift in the Republican vote share is workers concerned about their jobs, manufacturing employment should be a better predictor of the shift in the vote share than manufacturing capital. Thus, the fact that adding manufacturing capital per capita does not significantly change the results offers further evidence that the proposed mechanism drives the results.

Finally, I conduct two falsification tests in Table 5, seeing if the variables that have explanatory power for the shift in Republican vote share between 1860 and 1864 also have predictive power before and after this period. Significant coefficients with the sign seen above would lessen the legitimacy of the results during the time period under study by suggesting that the results could be due to another trend. The 1856 election was similar to that

\footnotetext{
${ }^{24}$ Manufacturing constituted $5.93 \%$ of employment in New York, $7.73 \%$ of employment in Pennsylvania, and $14.01 \%$ of employment in Connecticut.
} 
Table 3 Change in fraction Republican vote share between 1860 and 1864: other controls

(1)

$0.400^{* * *}$

(2)

(3)

(4)

(5)

Employment in manufacturing

[0.119]

Employment in non-military manufacturing

Fraction of population of foreign origin

Log population density (persons/sq. mi.) $-0.186^{* * *}$

$0.00878^{* *}$

[0.00420]

Fraction of vote won by Republicans in $1860-0.0911^{* *}$ [0.0370]

$\begin{array}{ll}0.384^{* * *} & 0.362^{* * *} \\ {[0.116]} & {[0.116]}\end{array}$

$0.393^{* * *}$
$[0.117]$

$0.364^{* * * *}$

$-0.193^{* * *}$

$$
-0.201^{* * *}
$$

$$
\text { [0.0385] }
$$

[0.0394]

[0.0427]

[0.0426] $0.0117^{* * *}$

$0.0115^{* * *}$

$0.0107^{* * *}$

$0.00825^{*}$

[0.00390]

[0.00399]

[0.00385]

[0.00432] $-0.0852^{* *}$ [0.0365]

Employment manufacturing weapons and 2.759

gunpowder

[2.851]

Church seats per capita

$-0.0184^{*}$

[0.0109]

[0.0117]

Cash value of farms per capita

Constant

\begin{tabular}{lllll}
$-0.0807^{* *}$ & $-0.150^{* * *}$ & $-0.127^{* * * *}$ & $-0.118^{* * *}$ & -0.0576 \\
{$[0.0354]$} & {$[0.0284]$} & {$[0.0245]$} & {$[0.0262]$} & {$[0.0382]$} \\
$\times$ & $\times$ & $\times$ & $\times$ & $\times$ \\
716 & 674 & 678 & 713 & 640 \\
0.528 & 0.513 & 0.52 & 0.521 & 0.532 \\
\hline
\end{tabular}

State dummies

Observations

$R^{2}$

0.528

*Significant at the $10 \%$ level

** Significant at the $5 \%$ level

*** Significant at the $1 \%$ level

Note: Robust standard errors are in brackets. The regressions are population-weighted. The employment variables are measured as a fraction of total county population

Source: Clubb et al. (2006), Geospatial and Statistical Data Center (2004), and 1860 Census of Manufactures

of 1860 in that both threatened to break apart the Union if the Republicans won. ${ }^{25}$ Thus, absent trends existing before the 1860 election which might be problematic for the main regressions above, we would expect little shift in Republican vote share between 1856 and 1860. The regressions in these columns are very reassuring. ${ }^{26}$ Columns (1)-(3) are falsifica-

\footnotetext{
${ }^{25}$ The loss of the Republican candidate John C. Fremont to the Democratic candidate James Buchanan in the 1856 election between was widely seen as a result of a desire to keep the Union together. Bailey et al. (1998) note that, "Perhaps more damaging [to Fremont than even his personal foibles] were the violent threats of the Southern 'fire-eaters' that the election of a sectional 'Black Republican' would be a declaration of war on them, forcing them to secede. Many Northerners, anxious to save both the Union and their profitable business connections with the South, were thus intimidated into voting for Buchanan" (Bailey et al. 1998; see also O'Connor 1968: 122). Similarly, the New York Times wrote, "The Southern press, of every political shade of opinion, with hardly an exception, threatens disunion in the event of defeat in the present contest for the presidency" (New York Times, August 29, 1856, quoted in Potter 1942).

${ }^{26}$ The regressions exclude counties which changed boundaries between 1850 and 1860 according to Thorndale and Dollarhide (1987).
} 
Table 4 Change in fraction Republican vote share between 1860 and 1864: other robustness checks

(1)

Employment in manufacturing

Fraction of population of foreign origin

Log population density (persons/sq. mi.)

Manufacturing capital invested per capita

$(\$ 1000)$

Constant

State dummies

Weights

Includes boundary-changing counties

Observations

$R^{2}$

*Significant at the $10 \%$ level

${ }^{* *}$ Significant at the $5 \%$ level

*** Significant at the $1 \%$ level

Note: Robust standard errors are in brackets. The employment variables are measured as a fraction of total county population

Source: Clubb et al. (2006) and Geospatial and Statistical Data Center (2004)

tion tests for the change in vote share between 1856 and $1860 .{ }^{27}$ Manufacturing employment is insignificant, close to zero, and fairly precisely estimated in all three specifications.

Columns (4)-(6) show falsification tests for the change for 1864 to 1868 . While the Civil War was over in 1868 , the vote was largely a matter of the ability of the North to maintain its hegemony over the South, similar to the goals in 1864. Republicans in 1868 threatened that voting Democratic would be akin to reopening the Civil War. Since the goal of keeping the South in the Union had been accomplished, we might expect some decline in the Republican vote share in areas with manufacturing, but perhaps not so much as to mask trends in the other direction which would call into question the above results. The results in these columns are close to zero, insignificant, and precisely estimated. The absence of any positive and statistically significant results reassures that the results in the main regressions are not the result of existing trends.

Overall, several features of the regressions here provide strong evidence that the relationships shown are not the result of omitted variable bias. The results are robust to the inclusion of state dummies, a variety of controls, and not having weights. Importantly, there is no evidence of pre-trends or post-trends in any of the relevant economic variables which could undermine the main results.

\footnotetext{
${ }^{27}$ To calculate the Republican vote share, I include the vote shares for the Republican Party and for the nativist American Party, most of whose voters migrated to the Republican Party.
} 
Table 5 Change in fraction Republican vote share: falsification tests

\begin{tabular}{|c|c|c|c|c|c|c|}
\hline & (1) & (2) & (3) & (4) & $(5)$ & (6) \\
\hline & \multicolumn{3}{|c|}{1856 to 1860} & \multicolumn{3}{|c|}{1864 to 1868} \\
\hline Employment & -0.113 & 0.0156 & 0.0506 & -0.0573 & -0.0708 & 0.0563 \\
\hline in manufacturing & {$[0.142]$} & {$[0.0847]$} & {$[0.122]$} & {$[0.0437]$} & {$[0.0755]$} & {$[0.0625]$} \\
\hline Fraction of population & & & $0.0600^{*}$ & & & $0.0993^{* * *}$ \\
\hline of foreign origin & & & {$[0.0363]$} & & & {$[0.0367]$} \\
\hline Log population density & & & $-0.00620^{*}$ & & & $-0.0147^{* * *}$ \\
\hline (persons/sq. mi.) & & & {$[0.00342]$} & & & {$[0.00426]$} \\
\hline Constant & $-0.0321^{* * *}$ & 0.018 & 0.0313 & $0.00541^{* *}$ & 0.0135 & $0.0462^{* * *}$ \\
\hline & {$[0.00604]$} & {$[0.0221]$} & {$[0.0224]$} & {$[0.00231]$} & {$[0.0116]$} & {$[0.0107]$} \\
\hline State dummies & & $x$ & $x$ & & $\times$ & $\times$ \\
\hline Observations & 586 & 586 & 586 & 749 & 749 & 749 \\
\hline$R^{2}$ & 0.007 & 0.719 & 0.725 & 0.001 & 0.054 & 0.081 \\
\hline
\end{tabular}

* Significant at the $10 \%$ level

** Significant at the $5 \%$ level

*** Significant at the $1 \%$ level

Note: Robust standard errors are in brackets. The regressions are population-weighted. The employment variables are measured as a fraction of total county population

Source: Clubb et al. (2006) and Geospatial and Statistical Data Center (2004)

\section{Interpretation}

Even having addressed many questions of omitted variable bias, to interpret the results as coming from a concern for keeping the South in the Union, I must argue that there are not other omitted variable bias problems or other concerns of the manufacturing sector that could have caused this shift. As described above, there are good economic reasons to believe that manufacturing industries would be concerned about the South leaving the Union. Here, I argue that there do not seem to be other explanations of the results above.

Although tariff politics were important during this time period, they imply a shift in the direction opposite to that which we see. With the much higher rates of the Morrill Tariff, passed in early 1861, tariffs became a less important issue for Northern manufacturing interests (Taussig 1910). Since the Democratic Party supported low tariffs while the Republican Party supported high ones, manufacturers assigning less importance to lower tariffs would predict shifts from 1860 to 1864 toward the Democrats, not the Republicans. Thus, the effect of concerns for the tariff would, if anything, decrease the magnitude of the results.

A second issue could be that it was not concern for keeping the South in the Union, but rather profiting from the war itself, that drove manufacturing interests. However, I controlled for the armament industry, and the results did not change. More importantly, if profiting from the war were an important motivation, one would predict that manufacturers would anticipate the benefits from the war in 1860 and vote Republican in both 1860 and 1864, leading to little shift.

A third question might be what was happening to interests other than those I test for, like agriculture, over the time between 1860 and 1864: perhaps they were trending away from the Republicans in ways that make it appear that the economic interests whose effects I $a m$ testing are increasing their support for the Republicans. Indeed, as Weingast (1998) 
argues, coalitions were shifting around this time: partly because of increased immigration, Northern business interests became more willing to accept western expansion through the provision of free land. So perhaps farmers in the East or West may have been more willing to vote for Republicans, who were increasingly favorable to land distribution, instead of the pro-agrarian Democrats, across time. However, this factor merely strengthens the results above, since the effects of the agricultural interest are trending in the same direction as the economic interests for which I am testing. In any case, though, as noted above, controlling for per capita agricultural interests does not affect the results.

Fourth, one might be concerned that manufacturers switched toward the Republicans because the Republican platform became more favorable to them from 1860 to 1864 relative to that of the Democrats. There are several reasons why this is unlikely to be the case. First, the same Republican candidate was running in both elections. More importantly, if anything, the Republicans were less sympathetic to the concerns of manufacturers in 1864 than 1860 as the war consumed most of the parties' attention. For example, among manufacturing interests, the 1860 Republican Party platform mentions the tariff, "development of the industrial interest of the whole country," appropriations for river and harbor improvement, and a railroad to the Pacific, while the 1864 platform mentions only the railroad to the Pacific. The Democrats mention industrial policy in neither document. War and the Union were dominant issues in these elections, even more so in 1864 , since the country was engulfed in the conflict. To the extent that shifts in platform may have also led to shifts in votes, it is likely that they would lead to shifts away from Republicans in the manufacturing sector from 1860 to 1864 .

Fifth, another potential concern might be that soldiers' absence from the data in 1864 but not 1860 could lead to omitted variable bias. However, for the absence of soldiers in 1864 to explain these results, soldiers would have to be either disproportionately Democrats from areas with lots of manufacturing or disproportionately Republicans from areas with little manufacturing. I am unaware of anything that supports either of these two scenarios. ${ }^{28}$

Sixth, a belief in 1860 that a potential war with the South would be a cheap, easy win cannot explain the results. ${ }^{29}$ If a war would both be low-cost and have a very high likelihood of regaining the South, then there would be no tendency for voters with manufacturing interests to vote for Democrats in 1860. A war would essentially not matter, neither costing them taxes nor risking the loss of the South, so they could vote for the Republicans without concern. However, this factor would reduce the shift toward Republicans, not increase it, since there would be fewer Democratic votes in areas with large amounts of manufacturing in 1860 .

Finally, Anderson and Tollison (1991) find that states with more electoral votes per capita had lower casualty rates. This would bias down the estimates if high-population states (which therefore had more electoral votes per capita) both had a lot of manufacturing and received unfavorable treatment during the war, leading to more discontent at home and a greater shift away from the Republicans. However, controlling for state removes the concern.

\footnotetext{
${ }^{28}$ One could also imagine more complicated stories about soldiers affecting voters at home or changed preferences of soldiers returning from war, but these seem unlikely to be related to manufacturing employment share.

${ }^{29}$ The plausibility of this belief is difficult to ascertain. Gunderson notes that "the Treasury and War departments and Congress all readily agreed that the war should last less than one year, require 300,000 troops and cost about $\$ 265,000,000$," but this analysis was not widely known (Gunderson 1974: 930). See also and Goldin and Lewis (1975) and Goldin (1973).
} 
Note how well these economic explanations fit with the standard story of resistance to war until the Fort Sumter attack and then support afterwards (Foner 1941). The Fort Sumter attack was precisely the point at which the best way to keep the South in the Union flipped from accommodation to war. The typical argument is that Northern preferences changed: the North was 'galvanized' by the attack on Fort Sumter and was then willing to be led into war. However, this galvanization also coincided with new information: the South was intent on seceding; the first-best option of peaceful re-unionization was no longer an option, so it was time to go to the second-best option. Thus, the standard story might be mistaking a change in information only for a change in preferences.

Stampp notes that, "because of their commanding political and economic positions the compromise drive was always spearheaded by eastern merchants and manufacturers" (Stampp 1970: 126). For example, "practically every prominent New York capitalist" met in December, 1860, to at least superficially appeal to the South for compromise. Bostonian businessmen acted similarly. However, once it was clear that it would take war to keep the South in the Union, areas that had been in favor of reconciliation turned quickly toward war. "Union rallies were most numerous in the large cities of the East and in the border areas of the West where the people favored conciliation overwhelmingly. There the specter of financial ruin made other issues shrink into insignificance" (Stampp 1970: 126). Thus, these economic hypotheses also agree with anecdotal evidence on the timing of changes in support for the war.

\section{Conclusion}

I have argued that an approximately 2.25 percentage point shift in voting for Republicans between 1860 and 1864 is attributable to the economic interests of manufacturing, a factor pivotal in states accounting for over a quarter of electoral votes. Causes other than a desire to keep the South in the Union seem unable to explain this shift, suggesting that a concern for keeping the South as part of the Union motivated this $2.25 \%$ of voters. If $2.25 \%$ of voters were on the margin between voting for the Democrats and Republicans and changed their votes to keep the South in the Union, then the actual fraction of the population with these economic interests was likely much larger, since many with this interest either kept voting Republican or were motivated enough by other concerns to keep voting Democratic. Thus, given that Lincoln could not have taken any action that did not reflect the will of at least a substantial part of the population, this paper offers strong evidence that economic motivations were one important component in the North's decision to fight the South after it seceded.

More broadly, this paper is a case study on why states tend to try to fight secessionist movements, even in democracies where leaders are less able to extract rents from seceding regions. These results suggest that powerful groups may benefit economically from having a union and that their influence may encourage countries to resist secession, even of relatively poor regions like the U.S. South.

Acknowledgements I would like to thank Dora Costa, Brad DeLong, Barry Eichengreen, Robin Einhorn, Jim Fearon, Jeffrey Hummel, David Laitin, David Liscow, Barry Weingast, William Woolston, and Gavin Wright, as well as two anonymous referees and the editor, for useful comments. Funding from the National Science Foundation and the University of California, Berkeley, is gratefully acknowledged. All errors are my own.

Open Access This article is distributed under the terms of the Creative Commons Attribution Noncommercial License which permits any noncommercial use, distribution, and reproduction in any medium, provided the original author(s) and source are credited. 


\section{References}

Anderson, G. M., \& Tollison, R. D. (1991). Political influence on Civil War mortality rates: the Electoral College as a battleground. Defense Economics, 2, 219-233.

Bailey, T. A. Kennedy, D. M., Cohen, L. (1998). The American pageant (11th edn.). Boston: Houghton Mifflin.

Bartkus, V. O. (1999). The dynamic of secession. Cambridge: Cambridge University Press.

Beard, C. A., \& Beard, M. R. (1927). The rise of American civilization (Vol. 1). New York: Macmillan.

Bolton, P., \& Roland, G. (1997). The breakup of nations: a political economy analysis. The Quarterly Journal of Economics, 112, 1057-1090.

Coakley, J. (1993). The territorial management of ethnic conflict. London: Frank Cass.

Clubb, J. M., Flanigan, W. H., \& Zingale, N. H. (2006). Electoral data for counties in the United States: presidential and congressional races, 1840-1972 [Computer File] ICPSR08611-v1.

DiLorenzo, T. J. (2003). The real Lincoln: a new look at Abraham Lincoln, his agenda, and an unnecessary war. Westminster: Crown Publishing Group.

DiLorenzo, T. J. (2006). Lincoln unmasked: what you're not supposed to know about dishonest Abe. New York: Crown Forum.

Egnal, M. (2001). The Beards were right: parties in the North, 1840-1860. Civil War History, 47, 30-56.

Fogel, R. W. (1989). Without consent or contract: the rise and fall of American slavery. New York: Norton.

Foner, E. (1970). Free soil, free labor, free men: the ideology of the Republican Party before the Civil War. London: Oxford University Press.

Foner, P. S. (1941). Business and slavery: the New York merchants \& the irrepressible conflict. Chapel Hill: University of North Carolina Press.

Foote, J. P. (1854). Letter to brother Samuel E. Foote, March 14. http://cgi.ebay.com/ws/eBayISAPI.dll? ViewItem\&ih=014\&sspagename $=$ STRK\%3AMEWA\%3AIT\&viewitem $=\& i t e m=330064672118 \& \mathrm{rd}=$ $1 \& \mathrm{rd}=1$. Accessed 28 January 2009.

Geospatial and Statistical Data Center, University of Virginia Library, Historical Census Browser. (2004). 1860 U.S. census of population and housing. http://fisher.lib.virginia.edu/collections/stats/histcensus/. Accessed 20 January 2009.

Goldin, C. (1973). The economics of emancipation. Journal of Economic History, 33, 66-85.

Goldin, C., \& Lewis, F. (1975). The economic costs of the American Civil War: estimates and implications. Journal of Economic History, 35, 299-326.

Gunderson, G. (1974). The origin of the American Civil War. Journal of Economic History, 34, 915-950.

Hummel, J. (1996). Emancipating slaves, enslaving free men: a history of the American Civil War. Chicago: Open Court.

Huth, P. K. (1996). Enduring rivalries and territorial disputes, 1950-1990. Conflict Management and Peace Science, 15(1), 7-42.

McPherson, J. B. (1988). Battle cry of freedom. New York: Oxford University Press.

Nagel, P. C. (1964). One nation indivisible: the Union in American thought, 1776-1861. New York: Oxford University Press.

North, D. (1961). The economic growth of the United States, 1790-1860. Englewood Cliffs: Prentice Hall.

O'Connor, T. H. (1968). Lords of the loom. New York: Charles Scribner's Sons.

Owsley, F. (1941). The fundamental cause of the Civil War: egocentric sectionalism. Journal of Southern History, 7, 3-18.

Persson, T., \& Tabellini, T. (2000). Political economics: explaining economic policy. New Haven: Yale University Press.

Porter, K. H. (1918). A history of suffrage in the United States. Chicago: University of Chicago Press.

Potter, D. M. (1942). Lincoln and his party in the secession crisis. New Haven: Yale University Press.

Ransom, R. L. (1989). Conflict and compromise: the political economy of slavery, emancipation and the American Civil War. Cambridge: Cambridge University Press.

Ransom, R. L. (2001). The economics of the Civil War. http://eh.net/encyclopedia/article/ransom.civil.war.us. Accessed 10 January 2009.

Rusk, J. G. (2001). A statistical history of the American electorate. Washington: CQ Press.

Silbey, J. H. (1985). The partisan imperative: the dynamics of American politics before the Civil War. New York: Oxford University Press.

Smith, G. (1992). The Lysander Spooner reader. San Francisco: Fox and Wilkes.

Stampp, K. (1970). And the war came: the North and the secession crisis, 1860-1861. Baton Rouge: Louisiana State University Press.

Stock, J. H., \& Watson, M. W. (2003). Introduction to econometrics. Boston: Addison-Wesley.

Taussig, F. W. (1910). The tariff history of the United States. New York: Knickerbocker Press. 
Thorndale, W., \& Dollarhide, W. (1987). Map guide to the U.S. federal censuses, 1790-1920. Baltimore: Genealogical Publishing.

Touval, S. (1972). The boundary politics of independent Africa. Cambridge: Harvard University Press.

U.S. Census Bureau (1970). International transactions and foreign commerce. http://www2.census.gov/prod2/statcomp/documents/CT1970p2-08.pdf. Accessed 5 January 2009.

Walter, B. F. (2006). Building reputation: why governments fight some separatists but not others. American Journal of Political Science, 50, 313-330.

Weingast, B. R. (1998). Political stability and civil war: institutions, commitment, and American democracy. In R. Bates et al. (Eds.) Analytic narratives. Princeton: Princeton University Press.

Williamson, C. (1960). American suffrage: from property to democracy, 1760-1860. Princeton: Princeton University Press.

Wright, G. (1978). The political economy of the cotton South: households, markets, and wealth in the nineteenth century. New York: Norton. 